UDC 930

\title{
HEALTH CARE IN THE BLACK SEA REGION IN LATE IMPERIAL RUSSIA AND IN WORLD WAR I
}

\author{
M. Conroy \\ University of Colorado at Denver, USA. \\ mary.conroy@ucdenver.edu
}

There is a prevailing myth that before the revolutions of 1917 and the advent of Soviet power, Imperial Russia did not produce factory-prepared medicines, requiring most or all such medicines to be imported.This article refutes that misconception, documenting from printed and archival sources that some 300 chemical, factories and some 100 pharmaceutical factories operated in Russia in 1913and that some zemstvos used only domestic medicines. The article emphasizes that before the $20^{\text {th }}$ century the vast majority of medicines were based on botanicals. This was true even after the discovery of sulfa drugs and antibiotics because some botanicallybased medicines were (and are now) superior to synthetics. Such was the case with quinine for malaria, endemic and epidemic throughout Imperial Russia and the Soviet Union.The article explains the reasons why Russia imported the new chemically synthesized medicines, the so-called "magic bullets," despite having prerequisites for production such as outstanding chemists and a large petroleum industry. The article emphasizes that the Russian pharmaceutical industry grew more robust during World War I because of synergy from many quarters and because the fetters on the industry were removed. The importance of the Black Sea Region is highlighted in the development of the Russian pharmaceutical industry before and during World War I.

Key words: Pharmaceutical Production, Russia, World War I, Black Sea Region, iodine

The myth that Imperial Russia imported most medicines from abroad has recently surfaced in the work of capable authors in their otherwise well-researched articles and books ${ }^{1}$.Actually, in the last two decades of the $19^{\text {th }}$ century and the first two decades of the

\footnotetext{
${ }^{1}$ For example, Dr. Juris Salaks alleges in his article, "The Operations of F. Hoffmann-La Roche in Russia From 1896 until 1920," published in the Proceedings of the Conference on History of Pharmacy held in Istanbul in September 2015, that "In the beginning of the $20^{\text {th }}$ century Russia depended completely on Germany in terms of supply of medicines...the lack of medicines and virtually non-existent competition from local producers were the determining factors that attracted (Hoffmann La) Roche's interest in Russia, where Roche was able to supply the missing unified high [quality medicines." It is true that Roche derived $25 \%$ of its profits from its Russian operations. However, it not true that in the second half of the $19^{\text {th }}$ and early $20^{\text {th }}$ century Russia did not have a domestic pharmaceutical industry. Russia did have such an industry; it supplied approximately half the factory-prepared medicine used. Yet, in her recently published dissertation from Maastricht University, Pharmapolitics in Russia (ISBN 978946159643 7) Olga Zvonareva, elaborates on the myth. On page 48 she quotes one OnisimMagidson who in 1970, opined: "Before the Revolution, the chemical and pharmaceutical industry of Russia consisted of small primitive enterprises the proprietors of which occupied themselves with commercial medicaments the care of patients, and perfumery and cosmetic products..." Zvonareva is not an historian. She is focused on the resuscitation of the pharmaceutical industry in present-day Russia and provides thoughtful information on this topic. However, in discussing the history of the industry before the Soviet era, she juxtaposes Magidson's work, with its vague statements about patient care and commercial medicaments, with my book, The Soviet Pharmaceutical Business During ItsFirst Two Decades, 1917-1937 (Peter Lang (2006, ISBN 8204 7899). My research in the Russian archives and in books and journals of the civil war period, 1920s NEP, and 1930s provides a very different
} 
$20^{\text {th }}$ century Russia had a thriving pharmaceutical industry that supplied approximately half the factory-prepared pharmaceutical and medical products used in the Empire. The industry grew stronger during World War I. What Russia - as the United States at the time-- did not produce were the chemically synthesized "Magic Bullets" on which German firms Bayer, Hoechst, and Merck had a lock through patents - as well as some medical devices purveyed by these firms-- and also some medicines produced by Swiss firms, Hoffmann La Roche, CIBA, and Sandoz. The reasons are explained below.

My 1994 publication, In Health and In Sickness (ISBN $0880332832-97808803328$ 39) provided 37 pages of nuanced examination ofthe Imperial Russian pharmaceutical industry documented with 22 pages of end notes consisting of archival materials and journal articles and books of the period. The Soviet Pharmaceutical Business(Peter Lang, 2006, ISBN 082047899 7)added more material on the industry before and during the First World War in 33 pages in chapters 1 and 2. The negative effects of Bolshevik nationalization on the industry,1918-1921, based on documents from the Russian State Archive of the Economy in Moscow RGAE)-and on published reports from the period, are discussed in chapter 3. In Health and In Sickness: Pharmacy, Pharmacists and the Pharmaceutical Industry in Late Imperial, Early Soviet Russia is a very large book. The Soviet Pharmaceutical Business During Its First Two Decades is smaller. However, perhaps both books are formidable for scholars whose first language is not English. In any case, because the myth that Russia imported most medicines from German and Swiss houses before the Great October Revolution and the advent of Soviet power is so pervasive--even amongst seasoned scholars--it seemed important to refute this myth in a more approachable version before moving to the topic of health care in the Black Sea Region.

An important primary source describing the growth of the chemical industry in Russia from the Crimean War through the third quarter of the $19^{\text {th }}$ centuryis Kozlov V.I. "Chemical products", chapter VIII. P. 1-101, Historical and statistical review of Russian industry, vol.III, editiedTemeryazev D.A. St.Petersburg, 1886. V. Kozlovemphasizes that the chemical industry grew exponentially following the Crimean War.

An important primary source continuing the development of the chemical industry and the pharmaceutical industry to the eve of the First World War is ХимическоеделовРоссии (Одесса, 1913). Columns 152 to 340 give details on the number of workers, products, and income of the pharmaceutical and chemical-pharmaceutical factories in the Russian Empire. This tome also provides illustrations of some of the enterprises.With 32 pharmaceutical factories,Moscow was the hub of the pre-revolutionary pharmaceutical industry. St. Petersburg came second. However, pharmaceutical factories existed in nearly every province. In the Black Sea Region, the factory of P. Legran and Company was established in Odessa in 1874; M. Krivitskii and F. G. Leviron established their factory in Odes-

picture from that of Magidson with regard to the chemical and pharmaceutical industry of Imperial Russia. Still, even the excellent historian Valentina Sosonkina, whose superb work Историяфармациибеларуси, 1918-1941 (Minsk 2014) 2016--ISBN 9789857091034 ), is based on extensive research in Belorussian archives and journals and newspapers of the period, repeats the myth on page 71: “Довойны 1914 годаРоссияпиталасьмедикаментамиипрочимисредствами, еслинецеликом, топреимущественноизГермании." Sosonkina meticulously documents the information about the pharmaceutical sector in her book where the fate of the sector during World War I was different than in the Russian heartland as Belarus was occupied by German troops-and by Polish troops during the Civil War. However, she does not document the myth about imports because it is so ingrained in public consciousness it needs no proof. 
sa in 1884.Some Russian pharmaceutical factories were small but many were large-such as the 13 factories in Riga-and exported their wares as well as selling them on the domestic market.

While some zemstvos considered foreign medicines not only cheaper but better, others ordered predominantly_and a few exclusively-- from Russian firms. For example, in 1898 the City Hospital in NizhniiNovgorod debated whether to order medicines from abroad or from Russian firms. In 1896, the Simbirsk provincial zemstvo sanitary bureau purchased medicines and supplies from nineteen Russian and four foreign firms. Between 1889 and 1910 the Tver' Zemstvo Warehouse bought 140,000 rubles' worth of medicines and wares from foreign firms compared with 193,000 rubles' worth from domestic enterprises. In 1910 the Tver' Zemstvo warehouse purchased pharmaceuticals from 37 foreign firms and 95 Russian ones. In Mogilev province medical authorities reported that zemstvos did not order medicines and supplies from abroad during 1913.

These points having been made, it is true that before the First World War, Russialike the United States before 1918-imported the new chemically synthesized "Magic Bullets" - aspirin, Salvarsan, novocaine, heroin, Dionin, phenacetinand other chemically synthesized febrifuges-- from German firms Bayer, Hoechst, Merck, and Farbwerke, turpentine from Schering, which operated in Russia, and Sirolin andDigalen from Hoffmann la Roche, headquartered in Basel but operating in Russia, along with other items coming from the Swiss firms CIBA and Sandoz.

Russia did not produce the magic bullets because she lacked talented chemists. In the 1780s, Tobias Lovits, an immigrant to Russia from Gottingen, discovered amethod of purifying water with charcoal,a process which the Russian government implemented to provide potable water for the military. In the first half of the $19^{\text {th }}$ century, A. F. Neliubin established a method of obtaining salts from quinine, created an apparatus for making ether, and analyzed arsenic. He analyzed proprietary medicines coming into Russia from abroad as well as those developed in Russia. His contemporary, M. Butlerov discovered urotropin and synthesized saccharin. In 1841, working at the University of Berlin, Nikolai Zinin produced a compound from nitrobenzene that was christened aniline by his colleague in St. Petersburg. Aniline became the basis for artificial dyes and then "the magic bullets." The research of George Dragendorff and his students at the University of Tartu in the 1860s and 1870s focused on plant alkaloids. Vladimir KarlovichFerrein did research on plants in his experimental garden; his large pharmaceutical factory included a research laboratory.A. V. Pel' investigated atropine, antiseptic and aseptic medical procedures, published 135 scientific articles, and was the first to extract Spermine in pure form which he sold in special sterile solutions and glass ampules developed by him. Spermine was sanctioned by the U. S. Formulary of 1918 and is still recommended against auto-immune diseases. Ferrein's factory in Moscow produced terpinhydrate, amygdalin, calcium carbonate, sulfuric barium, and calcium chloride. The Yaroslavl' factory produced benzoin preparation.It should also be noted that vaccines for scarlatina-streptococcus, typhus, dysentery, and other diseases were produced in separate institutes. Additionally, some 140 soap factories operated in Imperial Russia. Soap is one of the best preventatives against many communicable diseases. It was in critically short supply during the civil war of 1917/18-21 when communicable diseases like typhus grew exponentiallyand during the Soviet period-including during the Great Fatherland War. 
Further, as we have noted, Russia's petroleum industry, which could provide the coaltar by-products for the magic bullets, developed in the last decades of the $19^{\text {th }}$ century. The industry suffered losses during the upheavals of 1904/1905, but then strongly revived. By 1913, 7 superphosphate factories operated in the Empire,22 factories produced nitric acid, 26 produced hydrochloric acid, 16 produced aniline and benzol-from the Donbasswhich were refined in Riga, Moscow, Kovno, Kostroma, and Kurland. Nevertheless, initially, Russia imported the bulk of the benzol she used. In 19105793 пуд were produced domestically while 161,000 пуд were imported. On the other hand, Russian produced almost all the aniline used in the empire - in 19125 factories produced 105,000 пуд оf aniline oil and salts; only 19,000 пуд were imported. By World War I,production increased to 157,400 пуд with only 12,000 пуд imported. The major reasons Russia imported the magic bullets, as well as some raw chemicals, were three:

Firstly, the German and Swiss companies purveying them held the patents to these medicines. This permitted them, as Renate Reidl emphasized, to dominate the drug market. In the spring of 1911, Minister of Internal Affairs P. A. Stolypin advocated that Russian firms produce foreign patented medicines without obtaining a license stating on their labels made in Russia. This suggestion elicited outrage from the foreign firms. However, Stolypin's suggestion was implemented during the First World War.

Secondly, the policies of Imperial government ministries not only did not nurture the domestic chemical-pharmaceutical industry but curtailed it. Focused on resuscitation of the pharmaceutical industry in present-day Russia, Olga Zvonareva emphasizes the importance of government policy in this development. The Imperial Russian government negotiated low tariffs - to help the dye industry. This made it cheaper to import chemicals than to produce them. As important, the policies of the Medical Council in the Ministry of Internal Affairs were very deleterious to the pharmaceutical industry. The Medical Council made producers of medicines and medical devices jump through all manner of hoops, taking years to approve-or deny-- mass production of the item.

The third key reason for Russia's lag in competing with the chemically synthesized medicines was that plants remained the basis for most medicines into the $20^{\text {th }}$ century. European Russia and Siberia possessed a wealth of medicinal botanicals; for example willow bark served as a febrifuge. Moreover, one of Russia's main communicable diseases was malaria. Malaria was endemic and sometimes epidemic throughout the Volga River region up to the Arctic Circle as well as in the Caucasus and other southern areas. Malaria continued to be a scourge in the Soviet period; $25 \%$ of the Red army was sick with malaria in 1942; it was epidemic around Leningrad and in Belarus in 1945.Quinine was the only therapy for this debilitating and, in one form, fatal disease before synthetics were developed in the 1930s. In 1935 Russia began building the factory Akrikhin, on the foundation of two $19^{\text {th }}$ century chemical factories outside Moscow, to produce the synthetic, Akrikhin, reverse engineered from the German Atabrine. However,both had unpleasant side effects and quinine was often preferred to the synthetic.Malaria had been endemic along the Mississippi River Valley as far north as Minnesota until the 1880s, then receded. Still, in the 1920s the United States imported quinine from the Dutch, since it was considered that the best cinchona bark came from theDutch colony of Java. In any case, along with the chemical preparations cited on a preceding page, the Ferrein enterprises produced lozenges of quinine, morphine and arsenic - quinine and opiates being imported in Russia as explained below. 
The United States imported more plants from Russia than she exported to Russia. The main exports were licorice root, lycopodium, and sporyn'e. These continued to be exported during the First World War.Additionally, from the 1880s Russia had a monopoly on the roundworm expellant Santonin, produced from Artemesiacinain Chimkent, Turkestan. This product was crucialto the American hogindustry. It was distributed to hog producers by the Moorman Company in the state of Illinois.

In addition to quinine, however, Russia did need to import cocaine because coca plants did not grow in Russia. Russia also imported iodine (iod) and opium even though her long seacoasts contained seaweed for iod and opium poppies were cultivated in the empire, because the alkaloids of the domestic plants were not considered sufficiently strong to satisfy the Russian pharmacopoeia. Russia imported iod from Germany, which controlled the world's supply of this item--comprised of 65 percent of Chilean saltpeter and 35 percent of seaweed. lod was important as a disinfectant and to prevent goiter. Russia imported opium from the Ottoman Empire and Persia.

\section{World War I and the Black Sea Region}

During the First World War, Russia was supplied with chemicals and pharmaceuticals, in part, through nationalizing German firms that operated in the Empire and from Japan. But additionally and very importantly, the domestic pharmaceutical industry grew exponentially. Through cooperation between the Government, owners and managers of pharmaceutical factories, research pharmacists and scientists at universities, chemical and pharmaceutical societies, Orthodox monasteries, the Union of Zemstvos and Cities, and ordinary citizens medicinal botanicals were cultivated and collected;chemicals and pharmaceuticals heretofore imported from Germany and Switzerland were produced in existing factories in Moscow, Petrograd, Kiev, and elsewhere.

Modern Belarus had no pharmaceutical factories at the time of World War I but pharmaceutical warehouses and compounding pharmacies in Minsk, Mogilev and other Belorussian provinces were impacted by proximity to the front and German occupation following the Peace of Brest-Litovsk, 3 March 1918. Poland, with its important pharmaceutical industry was under German occupation by the fall of 1915. Evacuation of Factories from Riga interrupted supplies of medicines. However, existing and new factories and laboratories in the Russian heartland,and in Tashkent and Siberia compensated. For example, a factory to produce medical apparatus was established in Ufa.

The examples illustrating the growth of the Russian pharmaceutical industry during the war given in this present article are selective. Many examples cited in In Healthand In Sicknesshave not been repeated here in order to focus on the Black Sea area. For example, Ferrein, Keler and Company and other firms in Moscow, Petrograd, and so on produced medicines heretofore imported. Just one example of a new endeavor in Moscow was the laboratory established by Professor Chichibabin, who would play a role in the Soviet pharmaceutical industry, to produce morphine, dionin, heroin, codeine, atropine, and theobromine. Many existing factories in Ukraine and new factories - in Kiev, Khar'kov, Poltava, and elsewhereproduced products heretofore imported. By the end of the war, 120 manufactories existed in Ukraine. The Kiev Bacteriological Institute churned out vaccines against smallpox, gonococcus, cholera, typhus, scarlatina, streptococcus, diphtheria, as well as food supplements.As for the Black Sea region, a chloroform factory was created in Odessa. 
Great efforts were expended on gathering and cultivating medicinal botanicals that did not grow in Russia or were not fully exploited before the war. Because of its climate the Black Sea region was a key geographical area. Major pharmaceutical firms in Moscow, Petrograd, and elsewhere led the efforts. Those in the south and Black Sea area includedlu. Lemme and Company in Odessa, the Russian Society of Colonial Trade in Rostov-onDon, and the Caucasian Society of Pharmaceutical wares in Tiflis. The Russian government subsidized many of these projects, such as giving the Experimental Station for Research into obtaining Russian iodine at the Ekaterinoslav Mining Institute 50,000 rubles in 1914 to build a factory.Private contributions supplemented government funds. Prince Aleksandr Oldenburg, Director of the Sanitary and Evacuation Sector, gave 72, 325 rubles in 1915/1916 to the Sukhum Experimental Agricultural Station to establish a plantation of Medicinal plants on the Black Sea. A Magistr of Pharmacy managed the Plantation. The Sukhum Agricultural Society contributed an additional 10,000 rubles for purchase of seeds.

Botanists volunteered their expertise. The Society of Public Assistance organized cultivation of cinchona trees, camphor trees, and opium poppies in the Crimea and Black Sea Region, particularly near Sochi. In 1915, the Tiflis Botanical Garden, the Kiev Polytechnical Institute, The Imperial Nikitin Garden near Yalta under N. F. Kuznetsov, the Odessa Experimental Field under V. G. Rotmeister, the Medicinal Plant Section in the Sukhum Experimental Stationunder V. V. Markovichcultivated medicinal plants. Cultivation of kastorkafor castor oil had good results in the Crimea. The klehchevnyi plant was gathered for castor oil in Simferopol. Books on Collecting were published to help ordinary citizens participate. Special attention was expended on production of iod ( iodine), crucial for disinfecting, with particular focus on the Black Sea region. In 1914 Professor L. V. Pisarevskii of the Ekaterinoslav Mining Institute, Professor A. Zernov, and senior laborant N. D. Averkiev, who later played a role in the Soviet pharmaceutical industry, set up an experimental station to produce iod. It was derived from "red fillofora," a plant growing in the Black Sea. Research also showed that fillofora growing near Sevastopol and near Odessa also contained iodine of good quality. Ultimately collecting red fillofora farther out in the Black Sea became too dangerous, since the Ottoman Empire was an enemy, so plants growing on the shoreline were used. Initial experiments resulted in 3 and $1 / 2$ пуд of metallic iodine, the quality of which exceeded requirements of the Russian Pharmacopoeia. By the fall of 1915, a factory completed in March of that year, produced more than 10 фунт daily or 4 пуд per month of iod. Between March 1915 and 1918 the Odessa factory produced 1.000 kilograms of metallic iodine, 2. 500 kilograms of tincture of iodine (used as a topical disinfectant), 50 kilograms of various iodine preparations, and 3.000 tons of liquid disinfectants. Further research was conducted on extracting iod from the oily waters and dirt of the Crimea.

Several other iodine extraction stations were established. One in Tomsk produced 1.000 пуд оf iodine. Prince Oldenburg conducted experiments in 1915 in Murmansk. Professor V. E. Tishchenko and Arkhangel'sk merchants built an iodine factory in the White Sea area, deriving iodine from the ashes of seaweed and sea cabbage. Unfortunately, thisiod had a low alkaloid content. Stations on the Caspian Sea and the Sea of Okhotsk did produce higher quality iod. Production of iod in Tomsk at the end of 1916 amounted to 800 пуд; production of potassium salts to 60,000 пуд. Total production of iod was 2.000 пуд. Production of potassium salts was larger - 75.000 пуд. 
Russians reverse-engineered patented products heretofore imported from German and Swiss firms. The Medical Council assisted by swiftly approving more products. Thermometers, heretofore imported from Germany, began to be produced in Russia. The chemistry laboratory of the Sergeev pharmacy of E. M.Vestburg and Magistr of Pharmacy V. K. Tomson developed formulae for production of salicylic acid, ammonium salicylicum, lithium, natrium, sodium salicylate, and iodide salts. In March 1916 Moscow chemist I. I. Ostromyslenskii produced Russian "Salvarsan."This anti-venereal was named "Arsol" and was touted in advertisements in pharmacy journals. Although it was claimed that it could not be mass produced it was applied to patients in clinics with success.

In 1915, through coking, output of benzol and toluol increased significantly in the Donbass.During the first half of 1915, 97,000 пуд of benzol were produced in the Donetsk basin. Completion of a new factory in November 1915 was slated to increase production more.The Kazan Gas Factory produced benzol and built a facility to produce phenol and salicylic acid.In August 1916, R. Keler and Company in Moscow began producing phenol (pure carbolic acid) from Donetsk Basin coking although quantities were small.

The last issue of Farmatsevticheskiizhurnal, December15, 1916, noted that Russia surpassed Britain in production of phenol, benzol, and salicylic acid-produced there only in insignificant quantities and salol not at all.The Russian Laboratory of the Union of Cities had finished its experiments for production of phenacetin, had applied for a patent, and was beginning to produce phenacetin on a mass scale. Prices for salicylic acid and bromide preparations were falling. Prices of pharmaceuticals were particularly good in Odessa in the fall of 1916. Consequently, pharmacy owners suggested that the prices on theАптекарскаятакса (Pharmacyprice schedule) be lowered.

Archival documents detail that nationalization of pharmacies and pharmaceutical factories in Moscow and takeovers by workers and local governing bodies in other area from 1917/1918 through 1918-1921 ruined the pharmaceutical sector. Russia was faced with great shortages of medicines and soap during the civil war. Whereas the mortality rate for soldiers in the Imperial Army amounted to about $25 \%$, the mortality rate for civilians was hardly abnormal during the first three years of World War I. Communicable diseases increased astronomically during the civil war, felling an estimated 11 million-mainly civilians. Of course, the civil war was a different kind of war. Nevertheless, a comparison of disease and death during the civil war with disease and death during the first three years of World War I is just one more proof of the vitality of the pharmaceutical industry of Imperial Russia. It also puts the nail in the coffin of the myth that Imperial Russia imported most medicines from abroad,because she lacked a domestic pharmaceutical industry. Moreover, the performance of Russia's pharmaceutical sector during the first three years of World War l-before the advent of Soviet power-dispels the notion that the magic bullets could be applied to all diseases and medical problems. Finally, a look at the sector before and during the First World War gives credit to the contributions of the Black Sea Region.

\section{Лumepamypa}

Основные источники

Архивные документы:

1. РГАЭ (РоссийскийГосударственный Архив,Экономика.Москва) Ф. 8126, оп. 1. 
2. Центральный Государственный Исторический Архив, С.-Петербург. ф. 1298, оп. 1 , д. 2090 , л. 417.

3. ЦГИА

РБ (ЦентральныйГосударственныйИсторическийАрхивРеспубликиБашкортостан). Ф. 443, оп. 1.

Печатные издания:

1. Аверкиев Н.Д. О добыче йода в СССР из водоросли Черного моря 'Красная Филлофора' // Химико-Фармацевтический журнал. 1928. Т. 6. № 8 (56).

2. Ближайшие перспективы // Фармацевтический журнал. 1916. Т. 55. № 31.

3. Закупка медикаментов заграницей// Фармацевтический журнал. 1916. Т. 55. № 41.

4. Козлов В.И. Химические продукты/Историко-статистический обзор промышленности России редактором Тимирязевым Д.А. С.-Петербург, 1886. Т. 3.

5. К развитиюотечественного производства лекарственных материалов // Фармацевтический журнал. 1916. Т. 55. № 41.

6. Зайцев M.Е. Краткий очерк деятельности аптекарского склада Тверской губернского земства за истекшие 20 лет его существования 1889-1909 гг. Тверь, 1910.

7. Хроника: Завод лекарственных веществ// Фармацевтический журнал. 1916. № 7.T. 55.

8. Культура лекарственных растении // Фармацевтическийжурнал.1915. № 42. Т. 54.

9. Культура лекарственных растении в Крыму// Фармацевтический Журнал (Год. Том. Номер.) 1915. Т. 54. № 42.

10. Медикаментов русского производства // Фармацевтический журнал.1916. Т. 55. № 39.

11. Нижний Новгород// Фармацевтический журнал.1898. Т.20. № 46.

12.О добывании иода на Мурмане// Фармацевтический журнал.1916. Т. 55. №. 28.

13. Опытная станция по добыванию иода // Фармацевтический журнал1915. Т. 54. № 44.

14. Пересмотр таксу // Фармацевтический журнал.1916. Т. 55. № 31.

15. Препараты Киевскогобактериологического института //Жизнь фрармацевта.Т. 2. № 1.

16. Товарищество Феррейн: Производство химических и галеновых препаратов //Фармацевтический труд.1907. Т. 1. № 23, 29.

17. Садиков В. Война и состояние русской промышленности // Фармацевтический журнал.1915. Т. 54. № 35.

18. Смирнов Е. И. Опыт Советской медицины в Великой Отечественной Войны, 1941-1945. Москва, 1950-1955.

19. Сосаар М.И. По анкете что сделано нашей промышленностью за время войны// Фармацевтический журнал1916. Т. 55. № 29.

20. Thompson A.The Oil Fields of Russia and the Russian Petroleum Industry, 1908.

21. Устройствогородскогохимическо-фармацевтического завода. Доклад комиссии академика Н. С. Курнакова.Петроград, 1916.

22. Химическое дело в России. Одесса, 1913. 
23. Химическая промышленность //Фармацевтический журнал1916. Т. 55. № 3.

Второстепенные источники

1. Винокуров Г. A. АптекисимбирскойгуберниивХІХиначалечЧвекаХХвека //Фармация. № 19, 1970.

2. Conroy M. S. Emerging Democracy in Late Imperial Russia. University Press of Colorado, 1998.

3. Conroy M.In Health and In Sickness: Pharmacy, Pharmacists and the Pharmaceutical Industry in Late Imperial, Early Soviet Russia. Boulder, CO, East European Monographs, 1994.

4. Conroy M.Malaria in Late Tsarist Russia // Bulletin of the History of Medicine.1982. Vol. 56.No. 1.

5. Conroy M.The Soviet Pharmaceutical Business During Its First Two Decades. 1917-1937. Peter Lang Publishers, 2006.

6. Kikta T.NekropolFarmaceutycznycmentarzpowazkowski w Warsawie. Warsaw, 1985.

7. Натрадзе

A.

Г.ОчеркразвитиехимическофрармацевтическойпромышленностиСССР. Москва, 1967.

8. Reidl R.A Brief History of the Pharmaceutical Industry of Basel in Libenau, Jonathan; Higby, Gregory J. and Stroud, Elaine C. Pill Peddlers: Essays on the History of the Pharmaceutical Industry, Madison, WI. American Institute of the History of Pharmacy, 1990.

9. Salaks Dr.The Operations of F. Hoffmann-La Roche in Russia from 1896 until 1920 // Proceedings of the Conference on History of Pharmacy.Istanbul, 2015.

10. Сало В. М.АкадемикРоссийскойАкадемииНаукфармацевтТ. Е. Ловиц //Фармация.1975. Т. 24, № 1.

11. Сало В. М. Выдающийся деятель отечественной фрармации Георг Драгендорффф //Фармация, 1985.

12. Simon J. Pharmacy and Chemistry in the Eighteenth Century: What Lessons for the History of Science //Pharmacy in History.2015.Vol. 57. № 172.

13. СосонкинаВ.ИсторияфрармацииБеларуси, 1918-1941.Минск, 2014.

14.ZvonarevaO.Pharmapolitics in Russia: Making Drugs and Rebuilding the Nation. The Netherlands, 2015.

\section{References}

Primary Sources

Archival Documents

1. RGAE (Russian State Archive of Economics, Moscow) F. 8126, op. 1.

2. Central State Historical Archive, St. Petersburg f. 1298, op. 1, d. 2090, I. 417;

3. TsGIA RB (Central State Historical Archive of the Republic of Bashkortostan). F. 443 , op. 1.

Printed Materials 
1. Averkiev N.D. About the extraction of iodine in the USSR from the seaweed of the Black Sea 'Red Phyllophora' // Chemical-Pharmaceutical Journal. 1928.Vol. 6. No. 8 (56).

2. The nearest prospects // Pharmaceutical Journal. Vol. 55. No. 31. 1916.

3. Procurement of medicines abroad / / Pharmaceutical Journal. 1916. 55. No. 41.

4. Kozlov V.I. Chemical products // Historical and statistical review of the Russian industry by Timiryazev D.A. St Petersburg, 1886. Vol. III.

5. To the development of domestic production of medicinal materials // Pharmaceutical Journal. 1916. Vol. 55. No 41.

6. Zaitsev M. Ye. A brief outline of the activities of the pharmacy warehouse of the TverGuerniew Zemstvo for the past 20 years of its existence in 1889-1909. Tver, 1910.

7. Chronicle: Plant of medicinal substances // Pharmaceutical Journal. 1916. 55. No 7.

8. Culture of medicinal plants // Pharmaceutical Journal 1915. Vol. 54. No. 42.

9. Culture of medicinal plants in the Crimea // Pharmaceutical Journal 1915. Vol. 54. No 42.

10. Drugs of Russian manufacture // Pharmaceutical Journal1916. Vol. 55. No. 39.

11. Nizhny Novgorod // Pharmaceutical Journal 1898. Vol. 20. No 46.

12. On the extraction of iodine on Murman // Pharmaceutical Journal 1916. Vol. 55.No. 28.

13. Experimental station for the extraction of iodine // Pharmaceutical Journal 1915. Vol. 54. No 44.

14. Review of the tax rate // Pharmaceutical Journal 1916. Vol. 55. No. 31.

15. Preparations of the Kiev bacteriological institute // Life of the pharmacist.Vol.2. No1.

16. Partnership Ferrein: Production of chemical and galenic preparations // Pharmaceutical Journal.1907. Vol. 1. No. 23, 29.

17. Sadikov V.The War and the State of Russian Industry // Pharmaceutical Journal.1915. Vol. 54. No 35.

18. Smirnov E.I. Experience of Soviet medicine in the Great Patriotic War, 1941-1945. Moscow, 1950-1955.

19. Sosaar M.I. According to the questionnaire made by our industry during the war // Pharmaceutical Journal 1916. Vol. 55. No 29.

20. Thompson A. The Oil Fields of Russia and the Russian Petroleum Industry, 1908.

21. The device of the city chemical-pharmaceutical plant. Report of the commission of Academician N. S. Kurnakov. Petrograd, 1916.

22. ChemicalsinRussia. Odessa, 1913.

23. Chemical Industry // Pharmaceutical Journal 1916. Vol. 55. No 3.

\section{Secondary Sources}

1. Vinokurov G.A. Pharmacies of the Simbirsk Gubernia in the 19th and Early Centuries of the 20th Century // Pharmacia. 1970.No 19.

2. Conroy M. Emerging Democracy in Late Imperial Russia. University Press of Colorado, 1998.

3. Conroy M. In Health and In Sickness: Pharmacy, Pharmacists and the Pharmaceutical Industry in Late Imperial, Early Soviet Russia. Boulder, CO, East European Monographs, 1994. 
4. Conroy M. Malaria in Late Tsarist Russia // Bulletin of the History of Medicine.1982. Vol. 56.No 1.

5. Conroy M. The Soviet Pharmaceutical Business During Its First Two Decades, 1917-1937. Peter Lang Publishers, 2006.

6. Kikta T.NekropolFarmaceutycznycmentarzpowazkowski w Warsawie. Warsaw, 1985.

7. Natradze A.G. Essay on the development of the chemical-pharmaceutical industry of the USSR. Moscow in 1967.

8. Reidl R. A Brief History of the Pharmaceutical Industry of Basel in Libenau, Jonathan; Higby, Gregory J. and Stroud, Elaine C. Pill Peddlers: Essays on the History of the Pharmaceutical Industry, Madison, WI. American Institute of the History of Pharmacy, 1990.

9. Salaks Dr. Juris. The Operations of F. Hoffmann-La Roche in Russia from 1896 until 1920 // Proceedings of the Conference on the History of Pharmacy. Istanbul, 2015.

10. Salo V.M. Academician of the Russian Academy of Sciences pharmacist TE Lovits // Pharmacia.1975. Vol. 24. No 1.

11. Salo V.M. The outstanding figure of domestic pharmacy Georg Dragen-dorf // Pharmacia, 1985.

12. Simon J. Pharmacy and Chemistry in the Eighteenth Century: What Lessons for the History of Science //Pharmacy in History.2015.Vol. 57. № 172.

13. Sosonkina V. History of the Pharmacy of Belarus, 1918-1941.Minsk, 2014.

14. Zvonareva O.Pharmapolitics in Russia: Making Drugs and Rebuilding the Nation. The Netherlands, 2015. 